\title{
DOUBLE BLIND STUDY OF HYDROXYZINE, PROMETHAZINE, SECOBARBITAL, AND A PLACEBO FOR PREANAESTHETIC MEDICATION*
}

\begin{abstract}
Allen B Dobkin, M D, Krishan MALIK, M D., ANd Jacor S Israel, M D
\end{abstract}

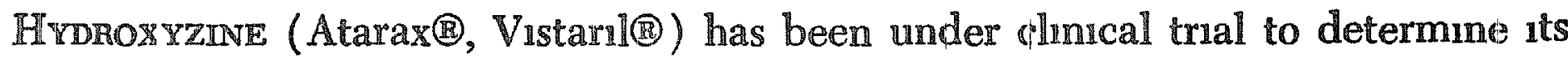
efficacy for pre-anaesthetic medication on the basis of its purported neurosedative, antihistaminic, antispasmodic, anti-emetic, and anaesthelic potentiating propertes ${ }^{1-6}$ Laboratory studies have shown that the intravenous injection of hydroxyzine causes a transient fall in blood pressure, an increase in coronary blood How, and suppression of epinephrine-induced ventricular arrhythmias ${ }^{7}$ The protective effect of hydroxyzme agannst arrhythmias is unrepliable ${ }^{8}$ In clinical tests, the therapeutic sedative dose has virtually no antisialogogue effect, ${ }^{9}$ nor does it disturb the blood pressure even when curculatory stress of 60-degree head-up tilt is used 10 No undesurable side effects have been reported clinically

Promethazine (Phenergan ${ }^{\circledR}$ ) has been used widely for pre-anaesthetic medication duing the past ten years, ${ }^{11-16}$ particularly when it is desirable to provide an antihistaminic effect ${ }^{17,18}$ It is a potent sedative, as dellermined by the potentiation of thiopental anaesthesia, ${ }^{8}$ is a powerful antisialogogue on account of its marked anticholinergic properties, ${ }^{19} 20$ and it has a minimall effect on the curculatory response to tilt ${ }^{21}$ The only drawback to its routme use is the frequent complaint by patients of a "twitchy" feeling, which appears to be a common effect of phenothiazine derivatives ${ }^{22} 23$

Secobarbital is a short-acting hypnotic sedative that has been used widely for pre-anaesthetic medication for many years It is recognazed to be effective and has virtually no undesirable effects, except that occasionally an elderly patient becomes confused during the half-asleep state that is induced, which increases the alarm if the patient is in an unfamiliar enviroriment This response is not uncommon with most of the barbiturate sedatives ${ }^{22}$

This report describes a double-blind study in which hydroxyzine, secobarbital and a placebo (coded unknowns) were compared with promethazine (coded, but known) for pre-anaesthetic medication

\section{METHODS}

Four hundred identical capsules were prepared of which 100 contained $50 \mathrm{mg}$

*From the Department of Anesthesiology, State University Hospital, State University of New York, Upstate Medical Center, Syracuse, New York, 13 \% 10

Can Anaes Soc J, vol 12, no 5, September, 1965 
hydroxyzıne (Vistanl@), 100 contained $50 \mathrm{mg}$ promethazıne (Phenergan®), 100 contaned $100 \mathrm{mg}$ secobarbital (Seconal()), and 100 contaned a placebo, lactose, and 2-ml brown ampoules were prepared, 100 containing $25 \mathrm{mg} / \mathrm{ml}$ hydroxyzine, 100 containing $50 \mathrm{mg} / \mathrm{ml}$ secobarbital, and 100 containing a placebo, salme Promethazıne was provıded in cartrıdges containing $25 \mathrm{mg}$ and $50 \mathrm{mg}$

A random-number table was used to alssign the three drugs and the placebo to a list of 400 consecutive numbers Envelopes containing a capsule for evening oral administration, and an ampoule of the same compound (or cartridge of promethazine) for morning intramuscular administration were labelled with the assigned number and sealed The envelopes with the drugs were placed in the hospital pharmacy and were requisitioned in numerical sequence $A$ sealed copy of the drug code was kept by the pharmacist until the study was completed and all data were tabulated

Each day following pre-anaesthetic rounds, adult patients who were scheduled for a major elective operation, who were judged to be fit for the contemplated surgical procedure, and for whom a general anaesthetic was considered appropriate, were assigned a consecutive coded drug number Those patients who were to have intracranial or cardiopulmonary procedures, and those who were to have short operations, were excluded 1rom the study $\mathbb{A}$ capsule of the coded drug was always prescribed for oral administration at the time of retiring, and a volume of the drug not exceeding $2 \mathrm{ml}$ was ordered for intramuscular injection one hour before the time of operation, alohg with 03 to $04 \mathrm{mg}$ scopolamine The volume of the coded drug piescribed was based upon the size, physique, and mental state of the patient Although all the preparations used were in numbered envelopes, the nurse who adminstered promethazine in each case would be able to identify this drug because it was supplied in a cartridge instead of an ampoule, so only three of the four preparations were considered as unknowns For each case that was studied, a questionnarre (see $\mathbb{F} 1 \mathrm{~g} 1$ ) was completed by a graduate nurse who was tranned for this study and assigned to it full-tume She abstracted information from the patient's chart pre-operatively, asked the patient direct questions immediately prior to induction of anaesthesia, and questioned the anaesthesiologist immediately following induction of anaesthesia All amaesthetics were supervised durectly by the authors, who used a uniform induction procedure (gallamine with thiopental), and mantenance of anaesthesia was carried out in most cases with either nitrous oxide-halothane or nitrous oxidemethoxyflurane and controlled respiration in a non-rebreathing system Postoperatively, the anaesthetic chart and the recovery room record were abstracted by the same nurse, she visited the patient 24 hours postoperatively to obtain pertinent information from the chart and to question the patient further, then the protocol was checked for completeness by one of the authors

At the conclusion of the study, all the information on the protocol sheets of 373 of the patzents (Fig 1) was tabulated and transferred to IBM cards The code was then revealed in order to analyze the data according to the compounds All data were analyzed statistrcally employing the chi-square test and $p$ values ${ }^{24}$ 


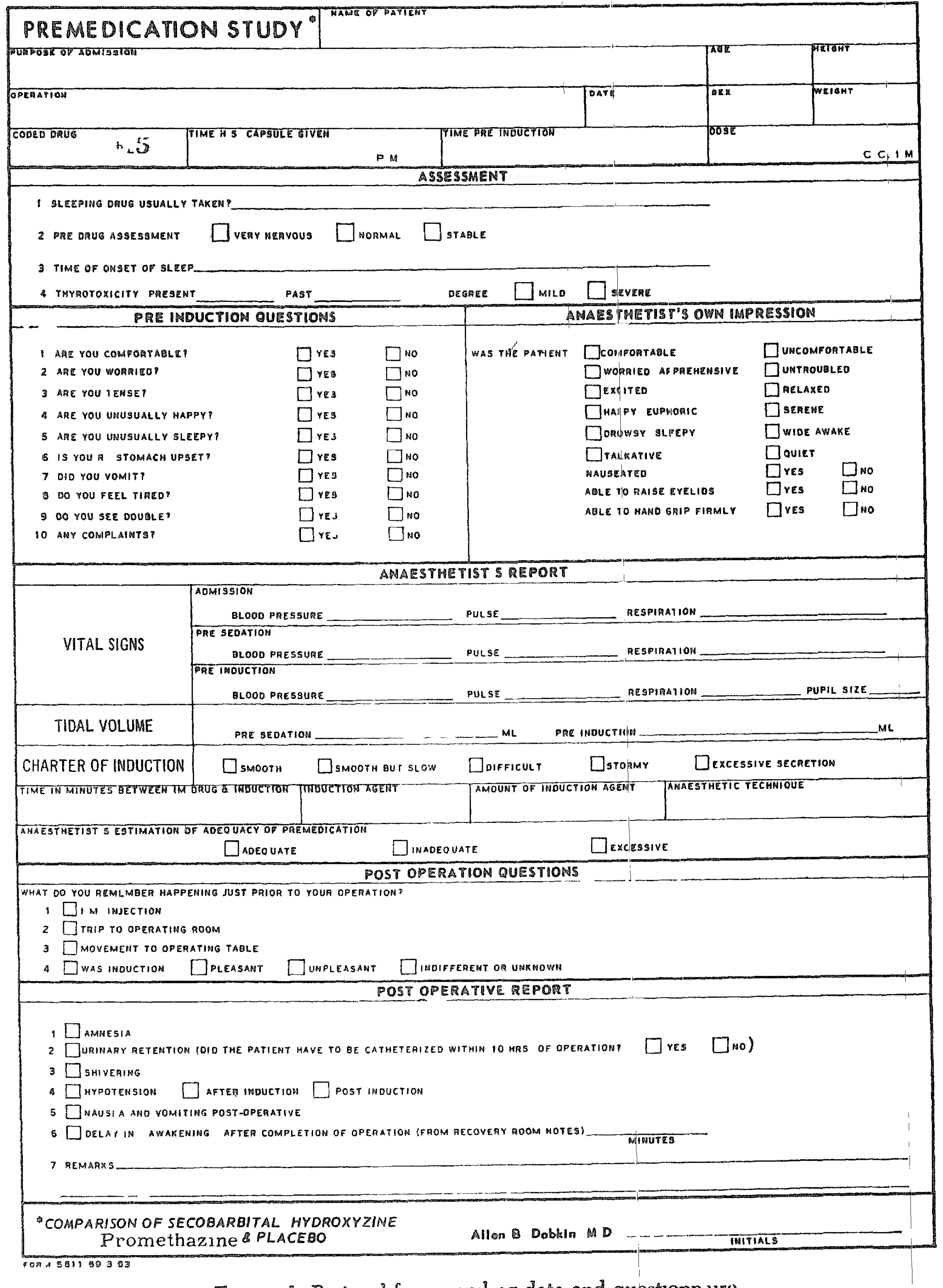

Figure 1 Protocol for compiling data and questionndure 
TABILE I

Patients' Answers to Direct Questions

\begin{tabular}{lcccc}
\hline & $\begin{array}{c}\text { Placebo, } 91 \text { pts } \\
(\%)\end{array}$ & $\begin{array}{c}\text { Promi thazine, } \\
96 \mathrm{pts} \\
(\%)\end{array}$ & $\begin{array}{c}\text { Hydroxyzine, } \\
90 \mathrm{pts} \\
(\%)\end{array}$ & $\begin{array}{c}\text { Secobarbital, } \\
96 \mathrm{pts} \\
(\%)\end{array}$ \\
\hline Discomfort & 2 & 9 & 7 & 7 \\
Apprehension & 37 & 36 & 32 & 37 \\
Excitement & 33 & 35 & 25 & 24 \\
Euphoria & 5 & 2 & 5 & 4 \\
Tiredness & 41 & 54 & 51 & 41 \\
Sleepiness & 33 & 41 & 41 & 41 \\
Nausea & 7 & 10 & 4 & 1 \\
Vomited & 1 & 1 & 2 & 1 \\
Diplopia & 3 & 6 & 3 & 28 \\
Complaints & 22 & 14 & 17 & \\
\hline
\end{tabular}

TABLE II

Anaesthesiologist's Impre',sion as to Patient's State

\begin{tabular}{lcccc}
\hline & $\begin{array}{c}\text { Placebo, } 91 \text { pts } \\
(\%)\end{array}$ & $\begin{array}{c}\text { Promethazıne, } \\
9 \text { pts } \\
(\%)\end{array}$ & $\begin{array}{c}\text { Hydroxyzine, } \\
90 \text { pts } \\
(\%)\end{array}$ & $\begin{array}{c}\text { Secobarbital, } \\
96 \text { pts } \\
(\%)\end{array}$ \\
\hline Discomfort & 8 & 8 & 5 & 6 \\
Apprehension & 38 & 42 & 27 & 35 \\
Excitement & 28 & 23 & 8 & 17 \\
Euphoria & 24 & 25 & 5 & 13 \\
Sleepiness & 39 & 57 & 60 & 59 \\
Nausea & 3 & 2 & 4 & 1 \\
Talkativeness & 6 & 12 & 8 & 9 \\
Lid lag & 1 & 3 & 1 & 8 \\
Weakness & 3 & 4 & 3 & 7 \\
\hline
\end{tabular}

TABLE III

Effect of Premedication on Vital Signs before Induction

\begin{tabular}{lcccc}
\hline & $\begin{array}{c}\text { Placebo, 91 pts } \\
(\%)\end{array}$ & $\begin{array}{c}\text { Promethazine, } \\
96 \mathrm{pts} \\
(\%)\end{array}$ & $\begin{array}{c}\text { Hydroxyzine, } \\
90 \mathrm{pts} \\
(\%)\end{array}$ & $\begin{array}{c}\text { Secobarbital, } \\
96 \mathrm{pts} \\
(\%)\end{array}$ \\
\hline Hypotension $(>20 \%)$ & 6 & 10 & 11 & 12 \\
Hypertension $(>20 \%)$ & 12 & 6 & 10 & 7 \\
Tachycardia $(>20 \%)$ & 4 & 9 & 14 & 6 \\
Bradycardia $(>20 \%)$ & 3 & 1 & 5 & 9 \\
\hline
\end{tabular}

TABLE IV

Erfect of Premcdication and Thionental Induction on Blod Pressure ( $>20 \%$ hypotension) during First 20 Minutes

\begin{tabular}{|c|c|c|c|c|}
\hline & Placebo, 91 pts & $\begin{array}{c}\text { Promethazine, } \\
96 \mathrm{pts}\end{array}$ & $\begin{array}{l}\text { Hydroxyzıne, } \\
90 \text { pts }\end{array}$ & $\begin{array}{c}\text { Secobarbital, } \\
96 \mathrm{pts}\end{array}$ \\
\hline $\begin{array}{l}\text { Halothane } \\
\text { Methoxyflurine } \\
\text { Others }\end{array}$ & $\begin{array}{c}5 / 22 \\
16 / 63 \\
1 / 6\end{array}$ & $\begin{array}{c}5 / 33 \\
1,5 / 59 \\
1 / 4\end{array}$ & $\begin{array}{c}4 / 38 \\
10 / 43 \\
1 / 9\end{array}$ & $\begin{array}{c}1 / 31 \\
17 / 57 \\
2 / 8\end{array}$ \\
\hline
\end{tabular}


TABLE V

Postoperative Responses during First 24 Hours Relatcd to Premedication

\begin{tabular}{|c|c|c|c|c|}
\hline & $\begin{array}{c}\text { Placebo, } 91 \text { pts } \\
(\%)\end{array}$ & $\begin{array}{l}\text { Promethazine, } \\
96 \mathrm{pts} \\
(\%)\end{array}$ & $\begin{array}{c}\text { Hydroxyzine, } \\
90 \text { pts } \\
(\%)\end{array}$ & $\begin{array}{c}\text { Secobarbital, } \\
96 \mathrm{pts} \\
(\%)\end{array}$ \\
\hline Hypotension $(>20 \%)$ & 2 & 2 & 2 & 7 \\
\hline Nausea and vomiting & 23 & 25 & 25 & 24 \\
\hline Urinary retention & 2 & 7 & 4 & 2 \\
\hline Shivering & 6 & 5 & 9 & 13 \\
\hline Delayed recover $\mathrm{V}(>30 \mathrm{~min})$ & 16 & 32 & 29 & 31 \\
\hline Amnesia & 6 & 16 & 13 & 17 \\
\hline Reacting in $\mathrm{OR}$ & 43 & 35 & 35 & 34 \\
\hline
\end{tabular}

TABLE VI

InCidence of Vomiting 24 Hours Posi|OPERATIVEly

\begin{tabular}{|c|c|c|c|c|c|c|c|c|c|c|c|c|}
\hline \multirow[b]{2}{*}{ Anaesthetic } & \multicolumn{3}{|c|}{ Placebo (91 pts) } & \multicolumn{3}{|c|}{$\begin{array}{l}\text { Promethazine } \\
\text { (96 pts) }\end{array}$} & \multicolumn{3}{|c|}{$\begin{array}{c}\text { Hydroxyzıne } \\
\text { (90 pts) }\end{array}$} & \multicolumn{3}{|c|}{$\begin{array}{l}\text { Secobarbital } \\
(96 \mathrm{pts})\end{array}$} \\
\hline & Cases & $\begin{array}{l}\text { Vom } \\
\text { (no) }\end{array}$ & $\begin{array}{l}1 \% \text { ited } \\
(\%)\end{array}$ & Cases & $\begin{array}{l}\text { Vom } \\
\text { (no) }\end{array}$ & $\begin{array}{l}\text { nited } \\
(\%)\end{array}$ & Cases & $\begin{array}{l}\text { Vom } \\
\text { (no ) }\end{array}$ & $\begin{array}{c}11 \text { ted } \\
(\%)\end{array}$ & Cases & $\begin{array}{l}\text { Vom } \\
\text { (no ) }\end{array}$ & $\begin{array}{l}\text { ted } \\
(\%)\end{array}$ \\
\hline Halothane & 22 & 7 & 32 & 33 & 5 & 15 & 38 & 9 & 24 & 31 & 7 & 22 \\
\hline Methoxyflurane & 63 & 14 & 22 & 59 & 17 & 29 & 13 & 12 & 28 & 57 & 16 & 28 \\
\hline Others & 6 & 一 & - & 4 & 2 & - & 9 & 2 & - & 8 & - & - \\
\hline
\end{tabular}

TABLE VII

Incidence of Delay in Recovery rrom Anaesthesia

\begin{tabular}{|c|c|c|c|c|c|c|c|c|c|}
\hline & & \multicolumn{2}{|c|}{ Placebo } & \multicolumn{2}{|c|}{ Promethazıne } & \multicolumn{2}{|c|}{ Hydroxyzine } & \multicolumn{2}{|c|}{ Secobarbital } \\
\hline & & Cases & $\begin{array}{l}\text { Awakened } \\
(\text { no })(\%)\end{array}$ & Cases & $\begin{array}{l}\text { Awakened } \\
\text { (no ) }(\%)\end{array}$ & Cases, & $\begin{array}{l}\text { Awakened } \\
(\text { no })(\%)\end{array}$ & Cases & $\begin{array}{l}\text { Awakened } \\
\text { (no })(\%)\end{array}$ \\
\hline 0 delay & $\begin{array}{l}\text { Halothane } \\
\text { Methoxyflurane }\end{array}$ & $\begin{array}{l}22 \\
63\end{array}$ & $\begin{array}{ll}11 & 50 \\
25 & 40\end{array}$ & $\begin{array}{l}33 \\
59\end{array}$ & $\begin{array}{l}1236 \\
2136\end{array}$ & $\begin{array}{l}38 \\
43\end{array}$ & $\begin{array}{ll}1539 \\
1228\end{array}$ & $\begin{array}{l}31 \\
57\end{array}$ & $\begin{array}{ll}1445 \\
1424\end{array}$ \\
\hline $\begin{array}{l}0-30 \mathrm{~min} \\
\text { delay }\end{array}$ & $\begin{array}{l}\text { Halothane } \\
\text { Methoxyflurane }\end{array}$ & $\begin{array}{l}22 \\
63\end{array}$ & $\begin{array}{rr}732 \\
2844\end{array}$ & $\begin{array}{l}33 \\
59\end{array}$ & $\begin{array}{ll}13 & 39 \\
18 & 30\end{array}$ & $\begin{array}{l}38 \\
43\end{array}$ & $\begin{array}{ll}17 & 45 \\
13 & 30\end{array}$ & $\begin{array}{l}31 \\
57\end{array}$ & $\begin{array}{ll}11 & 35 \\
19 & 33\end{array}$ \\
\hline $\begin{array}{l}>30 \mathrm{~min} \\
\text { delay }\end{array}$ & $\begin{array}{l}\text { Halothane } \\
\text { Methoxyflurane }\end{array}$ & $\begin{array}{l}22 \\
63\end{array}$ & $\begin{array}{rl}5 & 23 \\
10 & 16\end{array}$ & $\begin{array}{l}33 \\
59\end{array}$ & $\begin{array}{rr}824 \\
2135\end{array}$ & $\begin{array}{l}38 \\
43\end{array}$ & $\begin{array}{rr}6 & 16 \\
19 & 44\end{array}$ & $\begin{array}{l}31 \\
57\end{array}$ & $\begin{array}{rr}619 \\
2340\end{array}$ \\
\hline
\end{tabular}

\section{RESULTS}

Tables I to VII contain a summary of the pertment data that were abstracted from completed protocols obtaned on 373 patients Ampoule breakage accounted for 27 deletions

Statistical analysis of the data showed that the four treatment groups had equivalent distributions whth respect to age, sex, dosage, and primary anaesthetic given, indicating satisfactory randomization 
Preinduction Questions (see Table I)

A value of chi-square equal to or gieater than 60 indicated a statistically significant difference between the drugs at 05 probability level The chi-square test showed that there was no significant difference between the drugs and the placebo in the development of worry, euphoria, upset stomach, vomiting, and diplopia Fewer patients complaned of discomfort with the placebo, and significantly fewer patients complained of tenseness or excitement with hydroxyzine and secobarbital $(p<05)$ Significantly more patients were tired or sleepy with promethazine, hydroxyzine, and secobarbital than with the placebo ( $p<$ .01 ) and most complaints (usually that the patient did not sleep well) were found with the placebo and with secobarbital $(p=02)$ Considering all the preanaesthetic questions each patient was asked, and relating the answers to the preoperative sedation, we may rank the patients' preference for hydroxyzine or promethazine as higher than for secobarbital or the placebo

The anaesthesiologists' impressions (see Table II) in a similar analysis showed no significant differences in the incidence of discomfort or nausea. Fewer patients were apprehensive, excited, and euphoric with hydroxyzine than with the other agents used $(p<001)$, and apparent sleepiness occurred least often with the placebo $(p<001)$, while manifestations of agitation (apprehension, euphoria, talkativeness) were most common with promethazine $(p<02)$ Considering the over-all answers expressed by the anaesthesiologists, hydroxyzıne and secobarbital would be ranked higher than promethazine and the placebo

Combining the results of the answers by the patient and the anaesthesiologist, the sedatives may be ranked as follows hydroxyzine, secobarbital, promethazıne, placebo

Effect of Premedication on Vital Signs before and after Induction of Anaesthesia (see Tables III and IV)

The number of patients showing an increase, a decrease, or no change in bloodpressure levels between pre-sedation and pre-induction was not statistically significant although mild hypotension occurred less frequently with the placebo Tachycardıa occurred more often with hydioxyzıne, and bradycardia occurred more often with secobarbital, but in no case were these alterations alarming Hypotension of greater than 20 per cent following induction of anaesthesia appeared to be quite unrelated to the pre-operative sedative used That is to say, it appeared unlikely that any of the sedatives (including the placebo) affected the blood-pressure response to the induction of anaesthesia, and in none of the cases in this study did an alarming fall in blood pressure ( $>30$ per cent) occur immediately following the induction of anaesthesia

\section{Postoperative Report (see Tables V and VI)}

Ch1-square tests did not reveal any appreciable difference in postanaesthetic mcidence of hypotension or nausea and vomiting in the first 24 hours that could be related to the premedicants The groups were too small to relate the incidence of nausea and vomiting to the primary anaesthetic alone 
Amnesia occurred more frequently in the patients that received a drug for piemedication than those that recerved the placebo $(p<001)$, urinary retention requinng catheterization occurred more often in the patients who received promethazine $(p<05)$, and postanaesthetic shivering occurred more often in the patients who received secobarbital $(p<01)$

\section{Incidence of Delay in Awakening after Termination of Anaesthesia}

Fewer patients had zero delay in reacting in the operating room ( $1 \mathrm{e}$, were responsive to questions and instructions) that recerved premedicant drugs than those that received the placebo $(p<01)$ When the comparison was made with regard to recovery within 30 minutes of termination of the anaesthetic, this difference was striking $(\rho<001)$ When this effecl was related to the primary anaesthetics used, there was no consistent difference in effect (See Table VII)

\section{DisCUSSION}

It is now an established practice for the clinician to take every measure possible to eliminate prejudice and bias from the evaluation of new therapeutic measures ${ }^{25} 26$ Although the double-blind technique is ideal when the primary effects of the drugs to be compared are very similar, it may not be a fool-proof device when each of the drugs has certain side effects that the astute clinician can recognize ${ }^{2327}$ Nevertheless, if the study is well designed and carefully controlled, and if a proper balance is struck among the psychological and physiological factors that may be measured or evaluated subjecively and objectively, it is possible to approach the correct answer with somewhat more assurance than it one relies purely on clinical impressions 28

The authors recognized beforehand that it was essential to ensure sedation to some degree in every patient, because this is one of our primary duties On the basis of past expen ience, it was decided therefore that every patient in this study should receive scopolamine as the antisialogogue along with the placebo or any of the three sedatives, because scopolamine not only has some sedative properties of its own, but it also makes it difficult to identify the presence of other drugs which have predominantly hypnotic properties ${ }^{27,28}$ "The obvious disadvantage to using this method is that it tends to "di]ute" changes in effect that dufferentrate the drugs that are being tested and compared to an unert placebo However: we took into account the knowledge that as many as 50 per cent of the patients might appear to be "sedated" with the placebo alone, and that the broad approach to evaluating several psychological factors both subjectively and objectively would give us enough information to differentrate the placebo-scopolamine effect from that produced by the combination of scopolamine and one of the three sedatives

All the recorded factors were reviewed with respect to the main conditions one desires in a patient i esponding to a premedicant drug, such as general bodily comfort, sleepiness, and amnesia, the exclusion of excitement, euphoria, nausea, or other annoying complants, the absence of gros; changes in blood pressure and pulse rate before and after induction of anaesthesia, and the uncommon occurnence of unexpected delay in recovery from ancesthesia It was evident that 
the placebo was less effective than the three drugs that were tested although the over-all incidence of apprehension was disappointingly high It was also evident that promethazine appeared to be less effective in reducing the incidence of apprehension, excitement, euphoria, and talkativeness than the other sedatives, even though the occurrence of sleepiness and turedness were comparable Except for a somewhat higher incidence of complaints by the patients who received secobarbital (usually related to inadequate overnight sleep), there was little choice between it and hydroxyzine These findings are in essential agreement with the observations of Bizzarrı and associates ${ }^{2}$ In our study, no patient had an untoward response to any of the premedicants

It is apparent that it will take a much more widely documented experience to determine whether hydroxyzine has in fact much greater efficacy than secobarbital or promethazme As Modell has stated, "Do not fear about the good drugs, they will be recognized if they are placed in proper hands, will make themselves felt promptly, will be recognized for what they are, and they will survive Remember there is no guarantee that a new drug is better than an old one, the chances are less than even, and if you throw the weight of your experience into the balance, the odds against it are still longer Therefore, until the evidence is in, until after a drug's probationary period is over, I suggest that the value of experience be held in proper esteem and take precedence over shakily established claims and hurried use of new drugs "3o

\section{Summary AND CoNCLUSIONS}

A double-blind test was employed to compare the effect of three unknowns (hydroxyzine, secobarbital, and a placebo) with promethazine for pre-anaesthetic sedation on 373 adult patients who were being prepared for a major elective operation under general anaesthesia Each patient was given a capsule the night before, by mouth, and one hour before the operation the same compound was given intramuscularly, with scopolamine, to ensure an adequate antisialogogue effect and to help in preventing the identification of the sedative compound Data were collected on a special protocol which was completed for each patient by a nurse who was trained in this work The protocol contained information recorded from the initial pre-anaesthetic visit, before induction of anaesthesia (answers to direct questions by the patient), following induction of anaesthesia (answers to questions by the anaesthesiologist), and changes in vital signs and symptoms immediately after anaesthesia and during the first 24 hours after the anaesthetic Upon completion of the study, the data were tabulated and transferred to IBM cards All data were then analyzed statistically by means of the chi-square test The analysis revealed that the patients seemed to 1 eel better with hydroxyzine than with promethazine, secobarbital, or the placebo, in that order, whereas with the anaesthesiologist the order of preference was hydroxyzine, secobarbital, promethazine, and placebo. When the results were combined, the order preferred by the anaesthesiologist appeared to be the more valid

None of the sedatives appeared to have an appreciable effect on the blood pressure or pulse rate before or after induction of anaesthesia, nor did the pre- 
medicant drugs appear to influence the incidence of postanaesthetic hypotension or nausea and vomitung On the other hand, amnesia occurred more frequently in the patients who received drugs for sedation, and the incidence of slow recovery from anaesthesia was significantly higher among these as compared to the patients who received the placebo The only other postoperative symptoms that might be related to the sedatives were the occurrence of shivering, which was highest among those patients who received secobarbital, and urinary retention (requiring catheterization), which occurred most often with those receiving promethazine

Although the preferred order of the three sedatrves and the placebo was statistically valıd, the over-all differences were not great Only by careful documentation of the effects in a far larger series of patients will it be possible perhaps to obtain an unequivocal answer

\section{RÉSUMÉ}

Nous avons fart une étude à double-inconnu pour comparer les effets de trois substances inconnues (l'hydroxyzme, le sécobarbital et le placebo) avec la prométhazıne en prémédıcation chez 373 adultes qui devaient subir une opération majeure sous anesthésı gémérale $\mathrm{La}$ veille, chaque malade a pris par la bouche une capsule et, une heure avant l'opération, la même substance additionnée de scopolamme a été injectée dans le but de dimmuer la sécrétion salivaire et d'empêcher l'identufication de la substance sédative Les données ont été recueillies sur une feulle de protocole spéciale pour chaque malade et inscrites par une feulle de protocole spéciale pour chaque malade et inscrites par une infirmière qualifiée pour ce travall Ce protocole contıent des renseignements recuellis à partır de la première visite préanesthésique, avant l'induction de l'anesthésie (les réponses aux questions posées par le malade), à la suite de l'induction de l'anesthésıe (les réponses aur questions posées par les anesthésiologistes), les changements des sıgnes vitaux et des symptomes inmédiatement après l'anesthésie et durant les 24 premières heures après l'anesthésıe $\mathbb{A}$ la fin de l'étude, les données ont été accumulées et imprimées sur des caltes IBM Toutes les données ont alors été analysées statıstiquement en employant le test "chi square" L'analyse a révélé que les malades semblaient se sentir mieux avec l'hydroxyzme qu'avec la prométhazine, le sécobarbital et le placebo, dans cet ordre, alors que d'après le jugement de l'anesthésiste, l'ordre de préférence étart l'hydroxyzine, le sécobarbital, la prométhazıne et le placebo Lorsque les résultats furent cornbinés, l'ordre préféré par l'anesthésiologıste semble être le plus valide

Aucun des sédatifs ne semble produure un effet sensible sur la pression artérielle ou sur la vitesse du pouls avant ou après l'induction de l'anesthésie, il en est ainsı pour les médicaments donmés en prémédication, 1 ls ne semblent pas avour d'nfluence sur l'hypotension postanesthésique, les nausées et les vomissements D'autre part, nous avons observé plus souvent de l'amnésie chez les malades qui avarent reçu la médication sédative, et les réveils tardıfs se sont produits beaucoup plus fréquemment chez ces malades si on les compare à ceux qui ont recu du placebo Les seuls autres symptômes postopératoures qui peuvent se rattacher aux sédatifs sont le frisson qui a été plus tréquent chez les malades qui avarent 
reçu du sécobarbital, et la rétentıon d'urıne (nécessıtant une sonde) quı est survenue la plupart du temps chez ceux qui avarent pris de la prométhazine.

Bien que l'on place les trois sédatifs et le placebo dans un ordre de préférence statıstıquement valıde, les différences générales n'étaient pas grandes Pour avoir une réponse non équivoque, il faudrait une documentation soignée sur les effets de ces médicaments pour un groupe de malades beaucoup plus consıdérable

\section{ACKNOWLI DGMENTS}

This work was supported by a grant in and made by Pfizer Laboratories, New York City

Miss Christina Bisset, $\mathrm{R} \mathrm{N}$, was of great help by diligently and conscientiously interviewing the patients and abstracting the records during this study

\section{REFERIENCES}

1 Bizzarr, D, Latteri, F S, Schmoorler, A, Fierro, F E, Guiffrida, J, \& Berger, H C Preanesthetic Medication With Intravenous Hydroxyzine Anesth \& Analg. 40 378 (1961)

2 Bizzarru, D, Guiffrida, J, Fierro, F E \& \& Latteri, F S Preanesthetic Medication With Intramuscular Administration of Hydroxyzine Hydrochlonde A Parallel Double Blind Study of Hydroxyzıne Hydrochloride, Meperıdine Hydrochloride, Hydroxyzine Hydrochloride and Meperidine Hydrochloride, Secobarbital Sodıum and a Placebo Anesth \& Analg 42316 (1963)

3 Dobkın, A B, Israel, J S, \& Criswick, V G Prolongation of Thiopental Anaesthesia with Hydroxyzıne, SA 97, Thiethylperazıne, and Thıoridazıne Canad Anaesth Soc J 9342 (1962)

4. GRAdy, R W \& Rich, A R A Preliminary Report on the Use of Hydroxyzine (Vistarl) as a Premedicant for Surgical Patients J M A Alabama 29377 (1960)

5 Steindeng, N \& Holz, W G Preoperative Preparation for Tonsillectomy with Hydroxyzine Hydrochlorıde in Pediatric Patients New York J Med 60691 (1960)

6 Weyne, F \& Roussel, J L Hydroxyzme in Anesthesiology Bruxelles Med $37 \quad 51$ (1957)

7 Hutcheon, D E, Scriabine, A, \& Morris, D L Cardiovascular Action of Hydroxyzine J Pharmacol \& Exper Therap 118451 (1956)

8 Dobkin, A B \& Israel, J S The Effect of SA 97, Perphenazme, and Hydroxyzine on Epinephrine-Induced Cardiac Arrhythmias during Methoxyflurane Anaesthesia in Dogs Canad Anaesth Soc J 936 (1962)

9 Dobxin, A B, Woodworth, H, \& IsRael, J S The Antisialogogue Effect of Hydroxyzine, Thiethylperazine, and SA 97 Canad Anaesth Soc J 9 234 (1962)

10 Dobxin, A B, Robmoux, H J, \& Israge, J S Circulatory Response to Tilt With Hydroxyzine, Thiethylperazıne Maleate, SA 97, and Perphenazine Anesth \& Analg 42225 (1963)

11 Adelman, M H, Jaconson, E, Lnef, P. A, \& Mirler, S H Promethazine Hydrochlonde in Surgery and Obstetrics J A M.A 1695 (1959)

12 Carroll, J J \& Hudson, P W Chlorpromazine and Promethazine in Obstetrics Canad Anaesth Soc J 2340 (1955)

13 Carroll, J J \& MoIr, $R$ S Use of Promethazine (Phenergan) Hydrochlonde in Obstetrics J A M A 1682218 (1958)

14 SAdove, M S \& Frye, J Pre-Operative Sedation and Production of a Quiescent State in Children Promethazine-Mependıne-Scopolamine Sedation JA M A $164 \quad 1729$ (1957)

15 Watrous, W G Promethazine in Clinical Anesthesia Anesth \& Analg 3638 (1957)

16 DoBkIN, A B Potentiation of Thiopentone Anaesthesia Comparison of Promethazine, Chlorpromazıne, Perphenazıne, Fluphenazıne, Thiopropazate, Pipamazıne and Triflupromazine Brit J Anaesth 32424 (1960) 
17 Halpenn, B N \& Hamburger, I A New Synthetic Antihistammic Substance Dernved from Phenothrazine (Phenergan, 3277RP) Canad M A J 59322 (1948)

18 Heremenmer, $H$ Anthistamines in Bronchial Asthma Brst M J 2901 (1949)

19 Dobin, A B, WYant, G M, \& AAshem, G M. Antisialogogue Drugs in Man Companson of Some Anticholnergıc and Sedative-Antihistamine Drugs Anaesthesia 1363 (1958)

20 Naranjo, $\mathrm{P}$ \& DE NARANjo, E B Local Anaesthetic Adtivity of Some Antihistamines and its Relationship with Antihistaminic and Anticholinergic Activities Arch internat pharmacodyn 113313 (1958)

21 DoBIIN, A B, KrIL, A M, \& WONG, G Curculatory Response to Tilt with Phenothiazines Anaesthesia I6 160 (1961)

22 Dobrin, A B Sedatives, Analgesics, Antidotes, and then Interaction Canad Anaesth Soc I 11252 (1964)

23 Dobirn, A B \& Purkiv, N Double Bhnd Study of Phenothiazines Used in PreAnaesthetic Medication A Clinical Evaluation of Promiethazine (Phenergan(\$), Pro-

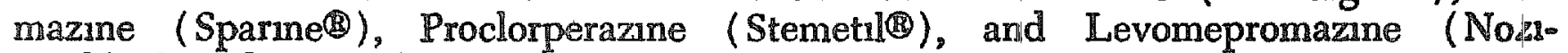
nan(B) Canad Anaesth Soc If 158 (1960)

24 Fisher, $\mathbb{R}$ A \& Yates $F$ Statistical Tables for Agricultural, Brological and Medical Research Edinburgh Oliver \& Boyd (1953)

25 BrECHFR, $H \mathbb{K}$ Experumental Pharmacology and Measulement of the Subjective Re. sponse Science 116157 (1952)

26 MODELL, W \& Houde, $\mathbb{R}$ W Factors Influencing Clnical Evaluation of Drugs with Special Reference to the Double-Blind Technique J A A 1672190 (1958)

27 Dobixin, A B, IsRAEL, J S, \& BYLES, $\mathbb{P}$ H Double Bind Study of Methotrumeprazine, Morphine, and Mependine for Preanesthetic Medication Anesth \& Analg (in press)

28 HeRring, $\mathbb{F}$ H Response durng Anesthesia and Surgery Psychosom Med 18 243 (1956)

29 Pedersen, $\mathbb{I} \mathbb{E}$ Scopolamine As Sole Pre-Anesthetic Medication Acta Anaesth Scandinav 7121 (1963)

30 Modell, W Safety in New Drugs I A M A 190141 (1964) 